\title{
Usage Pattern of Online Social Networking: Introvert and Extrovert Adolescent Boys
}

\author{
Maneesha Bhatt*
}

College of Community and Applied Science, Department of Human Development and Family Studies, Maharana Pratap University of Agriculture and Technology, Udaipur-Rajasthan, India

*Corresponding author

\section{A B S T R A C T}

\section{Keywords}

Usage pattern,

Online social networking,

Extrovert, Introvert and Adolescents

Article Info

Accepted:

28 March 2020

Available Online:

10 April 2020
The present study was undertaken to explore and compare the usage pattern of online social networking of 60 extrovert and introvert adolescent boys. Introversion-Extroversion inventory was utilized for sample selection. An inventory on online social networking was developed and utilized to assess the usage pattern of online social networking of extrovert and introvert adolescent boys. Percentage, mean percentage and t-test were computed for analysis of data. The results of the study revealed that usage pattern of online social networking in majority of extrovert and introvert boys was almost similar with little difference in few cases. No significant difference was observed among introvert and extrovert boys in usage pattern of online social networking.

\section{Introduction}

Man cannot live without society. Family is the first place for learning to be in the group. In recent years, new relationships have started with the arrival of man-made machines called computer and internet. The primary tools that enable socialization on internet are social networking sites and instant messages.

Social networking sites can be broadly defined as an internet-based social spaces designed to facilitate communication, collaboration and content sharing across networks of contacts. People use social networking sites for countless activities. Among the most common uses are, connecting with existing networks, making and developing friendships or contacts, viewing content or finding information, creating and customizing profiles and so on.

Online social networking sites 'virtually' link individuals, who may or may not 'know' each other. Facebook, Twitter, Yahoo, Chat Messengers and Skype are examples of online 
social networking sites. It is through these sites that people talk, share and exchange their joys, sorrows, day-to-day happenings, education, relationship etc. with each other.

Two factors are primarily responsible for the popularity of online social networking sites. Firstly, the networking factors itself, the ability to form different networks with people who share such things as location, day-to-day happenings, aspirations, hobbies and so on.

Secondly, the supposition that online users want to freely create and share their own content without having to undergo mundane task of setting up and managing their own websites.

Applications such as Facebook appeal to very large audiences and appeal to the inherent inquisitiveness we have about other people and what they are doing with their lives. The use of an online social network then becomes a way of sustaining communication and continued sharing of experience and learning.

Arnold (2014) in a recent survey found that in major cities such as Delhi, Mumbai, Kolkata, Chennai and Bangalore; Facebook emerged as the most popular social networking sites for the youths, while LinkedIn is the second most popular site. Almost $90 \%$ of the users join such sites to follow or stay in touch with their friends for pictures.

Various Western and Indian researches have been done so far on social networking. But limited Indian researches have been done on online social networking pattern of introvert and extrovert adolescents, the results of which are not explicit. Therefore, present study is being undertaken to get clear understanding of the usage pattern of online social networking of introvert and extrovert adolescents.

\section{Materials and Methods}

\section{Locale}

The present study was conducted in coeducational private schools located within the municipal limits of Udaipur city of Rajasthan.

\section{Sample selection}

Total sample consisted of 60 adolescents (30 boys under each extrovert and introvert categories) between the ages of 15-18 years, selected purposively from two co-educational private schools of Udaipur city.

\section{Tools and its description}

Introversion-Extroversion Inventory developed by Aziz and Agnihotri (2001) was used for sample selection. An inventory on online social networking was developed and utilized to assess the usage pattern of online social networking among extrovert and introvert adolescent boys. It consisted of items related to usage pattern and purpose of online social networking covering five areas in each aspect respectively. There were overall 33 statements. Each statement had four alternative responses i.e. mostly, sometimes, rarely and never which were scored as 3, 2, 1, 0 .

\section{Procedure of data collection}

An inventory on online social networking was administered to all 60 students selected for the study in both the schools on prescheduled date. The filling up of the inventory was preceded by brief introduction and orientation about the process and purpose of administering the inventory. They were requested to give honest responses and were assured that their identity would be kept confidential and information provided by them would be used exclusively for research 
purpose. Each respondent was given the inventory individually and was asked to fill out the inventory under the supervision of the researcher.

\section{Method of analysis of data}

Percentage and t-test was used to analyze the data statistically.

\section{Results and Discussion}

\section{Usage pattern of online social networking}

The results of the usage pattern of online social networking of extrovert and introvert boys have been portrayed in Table 1 .

Data from Table 1 unveils that most of the extrovert and introvert boys used Facebook as a social networking site that is, 60 percent and 70 percent extrovert and introvert boys respectively. None of the extrovert and introvert boys used Skype. The results are in line with Roy and Chakraborty (2015) findings which revealed that, Facebook is the most popular site among the adolescents as it provides individuals with a way of maintaining and strengthening social ties which can be beneficial in both social and academic settings.

Data presented in Table 1 also highlights that, 50 percent of extrovert boys and 46.67 percent of introvert boys became aware about social networking sites from peer group followed by mass media. It can be because mostly adolescents spend their time with peer group which act as a major source of information about any new updates and technological advancements like social networking sites. Mass media however occupies the second position as a source of information.

Regarding approximate time spent per day on social networking sites, results from Table 1 depicts that time spent by extrovert boys varies from 1-2 hours in 40 percent of cases and very few of them spent more than 2 hours. In contrast, time spent by introvert boys varies from less than 1 hour in 40 percent of cases and only one-tenth of them spent more than 3 hours per day on social networking sites. In the present findings, extrovert boys spent more time on online social networking than introvert boys in order to enhance their existing friend circle and social relationship with new people. Results are congruent to Myers-Briggs (2009) findings who stated that extroverts use social networking sites more often.

Data from Table 1 regarding preferred time of online social networking shows that nearly 50 percent of extrovert and introvert boys used online social networking sites at late night. It might be because many of them would perhaps have completed their homework and other activities by late night. Present findings are also congruent to the findings of Malhotra and Mahakud (2014) who found that most of the teenagers use online social networking at late night.

Results from the Table 1 regarding place of using social networking sites, reveal that majority of boys of both categories used social networking sites at home. Findings of the study suggests that majority of adolescents used online social networking at home. Probably, it might be because home is the only place where individuals spend most of their free time and beside this, number of households with internet facility might be very high in the city. Further, mobiles are not allowed in school premises.

Data from Table 1 further reveals that majority of extrovert and introvert boys used mobile for online social networking. Use of laptop and computer was meager for online social networking. The result of the present study get support from Lenhart (2015) who 
reported that due to convenience and constant access provided by mobile devices, especially smartphones, 92 percent of teens prefer it for online social networking.

Table.1 Percentage distribution of introvert and extrovert adolescent boys on the basis of usage pattern of online social networking

\begin{tabular}{|c|c|c|c|c|}
\hline \multirow{2}{*}{$\begin{array}{l}\text { S. } \\
\text { No. }\end{array}$} & \multirow[t]{2}{*}{ Items } & \multirow[t]{2}{*}{ Categories } & \multicolumn{2}{|c|}{ Boys } \\
\hline & & & $\begin{array}{c}\text { Extrovert } \\
\quad(\mathbf{n}=\mathbf{3 0})\end{array}$ & $\begin{array}{c}\text { Introvert } \\
(\mathbf{n}=\mathbf{3 0})\end{array}$ \\
\hline \multirow{5}{*}{1.} & \multirow{5}{*}{$\begin{array}{l}\text { Types of social } \\
\text { networking sites } \\
\text { used. }\end{array}$} & Facebook & 60 & 70 \\
\hline & & Twitter & 6.67 & 0 \\
\hline & & Yahoo & 10 & 3.33 \\
\hline & & Chat Messengers & 23.33 & 26.67 \\
\hline & & Any other & 0 & 0 \\
\hline \multirow{4}{*}{2.} & \multirow{4}{*}{$\begin{array}{c}\text { Source of } \\
\text { information about } \\
\text { social networking } \\
\text { sites. }\end{array}$} & Peer group & 50 & 46.67 \\
\hline & & Relatives & 13.33 & 20 \\
\hline & & Parents & 10 & 3.33 \\
\hline & & Mass media & 26.67 & 30 \\
\hline \multirow{4}{*}{3.} & \multirow{4}{*}{$\begin{array}{c}\text { Approximate time } \\
\text { spent per day on } \\
\text { social networking } \\
\text { sites }\end{array}$} & less than 1 hour & 33.33 & 40 \\
\hline & & 1-2 hours & 40 & 26.67 \\
\hline & & 2-3 hours & 13.67 & 23.33 \\
\hline & & more than 3 hours & 13.0 & 10 \\
\hline \multirow{5}{*}{4.} & \multirow{5}{*}{$\begin{array}{l}\text { Preferred time of } \\
\text { online social } \\
\text { networking }\end{array}$} & Early morning & 10 & 10 \\
\hline & & Day time & 3.33 & 10 \\
\hline & & Evening & 13.33 & 20 \\
\hline & & Late night & 53.33 & 40 \\
\hline & & Entire day & 20.01 & 20 \\
\hline \multirow{5}{*}{5.} & \multirow{5}{*}{$\begin{array}{c}\text { Place of using } \\
\text { social networking } \\
\text { sites. }\end{array}$} & Home & 93.33 & 86.67 \\
\hline & & School library & 3.33 & 3.33 \\
\hline & & Cyber cafe & 0 & 10 \\
\hline & & Hostel & 3.34 & 0 \\
\hline & & Any other & 0 & 0 \\
\hline \multirow{4}{*}{6.} & \multirow{4}{*}{$\begin{array}{l}\text { Device utilized for } \\
\text { online social } \\
\text { networking }\end{array}$} & Mobile & 93.33 & 83.33 \\
\hline & & Laptop & 3.34 & 13.34 \\
\hline & & Computer & 3.33 & 3.33 \\
\hline & & Any other & 0 & 0 \\
\hline
\end{tabular}

$\mathrm{n}=60$ 
Table.2 Comparative analysis of usage pattern of online social networking pattern among introvert and extrovert boys

\begin{tabular}{|c|c|c|c|c|c|c|}
\hline \multirow[t]{2}{*}{ S.No. } & \multirow[t]{2}{*}{ Categories } & \multicolumn{2}{|c|}{ Mean } & \multicolumn{2}{|c|}{ Standard deviation } & \multirow[t]{2}{*}{ t-value } \\
\hline & & $\begin{array}{c}\text { Introvert } \\
\text { boys }\end{array}$ & $\begin{array}{l}\text { Extrovert } \\
\text { boys }\end{array}$ & $\begin{array}{c}\text { Introvert } \\
\text { boys }\end{array}$ & $\begin{array}{c}\text { Extrovert } \\
\text { boys }\end{array}$ & \\
\hline 1. & $\begin{array}{l}\text { Usage pattern of online } \\
\text { social networking }\end{array}$ & 10.4 & 10.43 & 2.93 & 2.70 & $0.04^{\text {N.S. }}$ \\
\hline
\end{tabular}

Results from Table 2 clearly indicate that there was no significant difference between introvert and extrovert boys in usage pattern of online social networking. Present findings are supported by the findings of Hills and Argyle (2005) who found that usage of social networking sites was not much associated with differences in personality.

In conclusion, adolescents use online social networking for multiple purposes. Introversion and extroversion had its no effect in the usage pattern of online social networking in adolescent boys. To get better understanding of the present research it is recommended to extend this investigation to a larger sample size.

\section{References}

Arnold, M.N. (2014). Adolescents usage pattern of social networking sites. Journal of Computer-Mediated Communication.10: 419-422.
Aziz, P.F. and Agnihotri, R. (2001). Introversion Extroversion Inventory. National Psychological Corporation, Agra.

Briggs, M. (2009). Effect of social networking on adolescents. International Journal of Virtual Communities and Social Networking. 5: 76-79.

Lenhart, A. (2015). Teens, social media and technology. Journal of Library \& Information Technology. 29: 290-301.

Mahakud, G.C. (2014). A qualitative analysis of social networking usage. International Journal of Research and Development of Health. 2: 34-44.

Roy, S.D. and Chakraborty, S.K. (2015). Impact of social networking on education and life of undergraduate level students of Karimganj town- A survey. International Research Journal of Interdisciplinary and Multidisciplinary Studies. 1: 141-147.

\section{How to cite this article:}

Maneesha Bhatt. 2020. Usage Pattern of Online Social Networking: Introvert and Extrovert Adolescent Boys. Int.J.Curr.Microbiol.App.Sci. 9(04): 3105-3109.

doi: https://doi.org/10.20546/ijcmas.2020.904.362 